\title{
Die Apostoliese tradisie in die Kerk se verstaan van Skrif en geloof vanaf Reformasie tot aan die begin van die een en twintigste eeu - 'n Kort hermeneutiese oorsig
}

\begin{tabular}{|c|c|}
\hline $\begin{array}{l}\text { Author: } \\
\text { J.P. (Kobus) La }\end{array}$ & buschagne ${ }^{1}$ \\
\hline $\begin{array}{l}\text { Affiliation: } \\
{ }^{1} \text { Department } \\
\text { History and Pc } \\
\text { of Theology, U } \\
\text { Pretoria, Sout }\end{array}$ & $\begin{array}{l}\text { f Church } \\
\text { lity, Faculty } \\
\text { niversity of } \\
\text { h Africa }\end{array}$ \\
\hline $\begin{array}{l}\text { Note: } \\
\text { Dr J.P. (Kobus) } \\
\text { is research ass } \\
\text { Dr Graham Du } \\
\text { Department o } \\
\text { History and Pc } \\
\text { Theology, Uni } \\
\text { Pretoria, Preto }\end{array}$ & $\begin{array}{l}\text { Labuschagne } \\
\text { ociate of Prof. } \\
\text { Incan in the } \\
\text { f Church } \\
\text { lity, Faculty of } \\
\text { versity of } \\
\text { ria, South Africa. }\end{array}$ \\
\hline $\begin{array}{l}\text { Corresponden } \\
\text { Kobus Labuscl }\end{array}$ & $\begin{array}{l}\text { Ice to: } \\
\text { nagne }\end{array}$ \\
\hline $\begin{array}{l}\text { Email: } \\
\text { kobus.labusch } \\
\text { telkomsa.net }\end{array}$ & agne@ \\
\hline $\begin{array}{l}\text { Postal addres } \\
\text { PO Box } 38046 \\
\text { East, Pretoria } \\
\text { South Africa }\end{array}$ & $\begin{array}{l}\text { Garsfontein } \\
\text { 0060, }\end{array}$ \\
\hline $\begin{array}{l}\text { Dates: } \\
\text { Received: } 28 \\
\text { Accepted: } 12 \\
\text { Published: } 11\end{array}$ & $\begin{array}{l}\text { Apr. } 2015 \\
\text { June } 2015 \\
\text { Nov. } 2015\end{array}$ \\
\hline $\begin{array}{l}\text { How to cite th } \\
\text { Labuschagne, } \\
\text { Apostoliese tr } \\
\text { Kerk se versta } \\
\text { en geloof van } \\
\text { tot aan die be } \\
\text { een en twintig } \\
\text { Kort hermene } \\
\text { HTS Teologies } \\
\text { Theological St } \\
\text { Art. \#3018, } 15 \\
\text { dx.doi.org/10. } \\
\text { v71i3.3018 }\end{array}$ & $\begin{array}{l}\text { lis article: } \\
\text { J.P., 2015, 'Die } \\
\text { adisie in die } \\
\text { an van Skrif } \\
\text { af Reformasie } \\
\text { gin van die } \\
\text { ste eeu - 'n } \\
\text { utiese oorsig', } \\
\text { e Studies/ } \\
\text { udies 71(3), } \\
\text { pages. http:// } \\
4102 / h t s .\end{array}$ \\
\hline $\begin{array}{l}\text { Copyright: } \\
\text { (C) 2015. The A } \\
\text { Licensee: AOS } \\
\text { OpenJournals. } \\
\text { licensed under } \\
\text { Commons Attr }\end{array}$ & $\begin{array}{l}\text { IS } \\
\text { IS } \\
\text { This work is } \\
\text { the Creative } \\
\text { ibution License. }\end{array}$ \\
\hline Read online: & \\
\hline 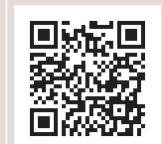 & $\begin{array}{l}\text { Scan this QR } \\
\text { code with your } \\
\text { smart phone or } \\
\text { mobile device } \\
\text { to read online. }\end{array}$ \\
\hline
\end{tabular}

The Apostolic tradition in the Church's understanding of Scripture and faith from Reformation to the start of the 21st century - A brief hermeneutical overview. This study is a concise hermeneutical overview of faith's various ways of understanding and of the different approaches towards scripture interpretation in the history of the Church, from the Reformation to the start of the 21st century. In conclusion, the research manifests that historically the Apostolic Tradition of the Early Church, with its ecumenically accepted expression of faith in the Nicene Confession (originating from the Ecumenical Councils of Nicaea 325 and Constantinople 381), provides us with a vital hermeneutical key for the interpretation of the scripture and the faith of the Church and, in conjunction with this, offers a foundation towards Church unity for our time and all centuries. The study expressly takes into account that the current ecumenical debate on the unity of the Church predominantly supports the view that the Nicene-Constantinopolitan creedal statement undoubtedly renders the best basis for seeking the unity of faith communities of all ages and across the world.

\section{Inleiding}

Hierdie studie wil 'n hermeneutiese kort oorsig aanbied van die prosesse van verstaan in die kerk se geskiedenis. Nadat in 'n vorige ondersoek (kyk Labuschagne 2015) reeds aandag gegee is aan die verloop van hierdie prosesse in die Vroeë Kerk, en waaruit die sentrale posisie van die Apostoliese tradisie sterk na vore gekom het, wil hierdie studie van daar af verder gaan en meer spesifiek aandag gee aan die periode vanaf die Reformasie tot aan die begin van die een en twintigste eeu. Die studie is beperk tot ' $n$ bondige ondersoek wat navors hoe geloof en Skrif verstaan word in die periode soos aangedui. Daar word, voortspruitend uit die vorige studie, nagevors oor die stand en voortgaande rol van die Apostoliese tradisie en die Konfessies van hierdie tradisie - veral omdat die Apostoliese tradisie in die Vroeë Kerk sterk figureer, en verder omdat dit vroeg reeds in die twintigste eeu deur die Ekumeniese Beweging geïdentifiseer is as 'n belangrike faktor in die strewe na die eenheid van die kerk oor die wêreld en deur die eeue. Die Konfessie van Nicea-Konstantinopel (325 en 381) is ekumenies deur die Faith and Order Movement by Lausanne so vroeg as 1927 reeds geïdentifiseer as die ekumeniese simbool van die eenheid en geloof van die kerk oor die wêreld en deur die eeue (Confessing the One Faith 2010:xxiii).

Hoewel daar histories verskillende hermeneutiese strominge en talle faktore van verstaan te onderskei is, is dit tog opvallend dat die Apostoliese tradisie gedurende verskeie periodes (soos by die Vroeë Kerk) na vore tree as die oorkoepelende model vir verstaan, in relasie tot ander aspekte van verstaan. Opsommend kan 'n aantal belangrike aspekte van die Apostoliese tradisie uitgewys word:

- Die Apostoliese tradisie verwys nie na 'n proposisionele waarheidsbeskouing nie. Die waarheid is nie in stellings van die kerk vasgevang en daarin verselfstandig nie.

- Die waarheid wat bely word in die Ekumeniese Konfessies is uitdrukking van die kerk se geloof en nie die grond van hulle geloof nie.

- Die geloof van die kerk spruit voort uit die gelowige se geloofsontmoeting met die lewende God, wat die gelowige in genade en liefde aangeraak het. Die waarheid van hierdie geloof het sy agtergrond in daardie waarheid wat van die apostels ontvang is en wat getrou van geslag tot geslag oorgedra moet word (na die betekenis van die Latynse woord trado, en waarvan die woord 'tradisie' afkomstig is). Dit bly steeds die roeping van die kerk om hierdie waarheid getrou oor te dra van geslag tot geslag, en inderdaad aan alle mense.

- Die getuienis van die apostels oor die evangelie van die Here Jesus Christus, oor sy kruis en opstanding, word in die Bybel berig en deur die Heilige Gees in die harte van gelowiges bevestig. 
- Die geloof van die Vroeë Kerk reageer op God se soewereine magsingryp in hierdie wêreld, dit volg op God se selfopenbaring in Jesus Christus, die Here, en dit is nie die produk van gewone menslike redenasies en spekulasie as verlengstuk (of projeksie) van menslike strewe en verlange nie - dit is nie die produk van menslik rasionele immanentisme nie.

- Die waarheid wat ontvang is, verwys na die werklikheid van gebeure rondom die persoon en werk van die Here Jesus Christus, en wat die apostels en hulle assosiate met hulle oë gesien het, met hulle ore gehoor het, met die hande aan gevat het, en dit aan die wêreld vertel het (vgl. Confessing the One Faith 2010:76-78, 100).

In ons ondersoek van die verlede is 'n metodologiese openheid noodsaaklik om die verlede die geleentheid te bied om ons aan te spreek, ons verstaan aan te spreek, sonder dat ons ons eietydse voorwaardes eensydig in skrywe in dit wat nou die deur ons gekontamineerde boodskap van die verlede word. Wat benodig word, tot die ontdekking van 'n nuwe meer omvattende insig, behels dat ons gedagtes en die boodskap van die teks by mekaar uitkom, in wat Hans-Georg Gadamer (1900-2002) 'n 'fusion of horizons' noem (Gadamer 2006:390).

Gadamer identifiseer tot verstaan kom met effek in sy uiteensetting van hoe 'n bewussyn werk, wat die effek ondergaan van die geskiedenis wat daarop inwerk. Hierdie bewussyn noem hy dan 'n wirkungsgeschichtliches Bewußtsein. Gadamer (2006:336) sê: 'Understanding proves to be a kind of effect and knows itself as such.' Hy (Gadamer 2006) konstateer ook:

When a naïve faith in scientific method denies the existence of effective history, there can be an actual deformation of knowledge ... Consciousness of being affected by history (wirkungsgeschichtliches Bewußtsein) is primarily consciousness of the hermeneutical situation. (bl. 300-301)

\section{Die kerk van die Reformasie - Terug na die bronne: Die Bybel en die Apostoliese tradisie (1500-1600)}

Anders as die geval in die Vroeë Kerk, maak'n proposisionele waarheidsbeskouing sy verskyning in die Middeleeue, wanneer die waarheid, op verbasende wyse, geobjektiveer word in die leerstellings en dogmas van die kerk. Die uitdrukking van die lewende geloof van die Apostoliese tradisie het vervaag. Lohse (1985) wys gevolglik onder andere op die volgende:

It was not until the Middle Ages that the Catholic church developed the doctrine of the depositum fidei, i.e., the conception that the church had been entrusted with a certain treasure of truths, none of which was to be lost; yet the treasure was capable of further development in the sense of a more explicit ramification of these truths. The full consequence of this conception was that modern Catholicism has claimed infallibility for its dogmas, as it did at the Council of Trent and at the First Vatican Council. The understanding of dogma as a revealed proposition of faith was thus by no means characteristic of the ancient church. (bl. 7, 8)
In die Middeleeue het die Vroeë Kerk se apostoliese suksessie ook verword, met nou 'n verskuiwing weg van die oorspronklike oordrag van die waarheid wat van die apostels ontvang is, na die oordrag van menslike posisies, mag en aansien (vgl. Van de Beek 2012:262).

Aquinas het in sy vermenging van teologie en filosofie uiteindelik ruimte gevind vir die twee dominerende Middeleeuse oortuigings van God se genade en menslike meriete (Walker 1968:247).

Die Reformasie verwerp die kerklike tradisie wat in die Middeleeue sy verskyning maak. Die Reformasiegeloof bring 'n terugkeer na die Bybel as gesagsbron en na die Apostoliese tradisie van die Vroeë Kerk wat verbind was tot die oorhandiging van die waarheid soos ontvang van die Here Christus en sy apostels. Wanneer Zacharias Ursinus (1534-1583), primêre outeur en finale redakteur van die 1563 Heidelbergse Kategismus (Bierma 2005:71-74), byvoorbeeld 200 bladsye van sy kommentaar op die Heidelberg se Kategismus gebruik om die Geloofsbelydenis van die Apostels te behandel, is sy aansluiting by die Apostoliese tradisie baie duidelik, veral ook wanneer hy verder verwys na die Vroeë Kerk se Konfessies as 'formed and received in the church' en dan spesifiek noem: '[T]he Nicene, the Athanasian, the Ephesian, and Chalcedonian' (Ursinus 2012:117). Ursinus (2012) - en dit is hermeneuties belangrik - verwys na die waarheid van die Konfessies:

$[I] \mathrm{n}$ their perpetual agreement with the holy Scriptures, and with the teachings of the whole church from the time of the Apostles, retaining and holding fast to the doctrine which they delivered, and at the same time giving testimony to posterity that they have received this doctrine from the Apostles and those that heard them. (bl. 118)

Van de Beek dui op Johannes Calvyn (1509-1564) se aansluiting by die Vroeë Kerk se verstaan en handhawing van apostoliese suksessie, en wat totaal anders was as die Middeleeue se afwyking daarvan - en wys dan op die belangrikheid van 'leer en leven', soos 'vasgelegd in die ordinatie die met handoplegging word voltrokken', diensbaar aan Christus en sy Kerk (Van de Beek 2012:262). Calvyn verwerp die Roomse hiërargie se misbruik van die biskopsamp, en verwys daarna as ' $[a]$ succession which abandons the truth of Christ' (Calvin 1964b:304) en beklemtoon die kern van waar dit op aankom in die Vroeë Kerk se apostoliese suksessie, naamlik die waarheid, wat bewaar moes word - 'the true Church is "the pillar and ground of the truth" (1 Tim 3: 15)' (Calvin 1964b:305). Met verwysing na Efesiërs 2:20 sê Calvin (1964b):

If the Church is founded on the doctrine of the apostles and prophets, by which believers are enjoined to place their salvation in Christ alone, then if that doctrine is destroyed, how can the Church continue to stand? (bl. 305)

Calvyn verwys in sy kritiek ook op die Roomse praktyk van 'n verworde suksessiebeskouing wat afgewyk het van die kerkvadere soos Irenaeus, Tertullianus, Origenes, Augustinus en ander in hulle getroue handhawing van die oordrag van die waarheid: 
[T]hey pretend that the Church ... was preserved from destruction by a perpetual succession of bishops. They dwell on the importance which Irenaeus, Tertullian, Origen, Augustine, and others, attached to this succession ... but ... they have laid aside all regard to truth, and make it their only aim to prosecute their own ends ... [T] he pretence of succession is vain, if posterity do not retain the truth of Christ, which was handed down to them by their fathers, safe and uncorrupted, and continue in it. (Calvin 1964b:306)

Die geloof wat die kerk bely, het histories deur verskillende periodes gegaan, waarin verskillende leerstellings van die kerk gekonfronteer is met verskillende vrae, bedreigings en uitdagings. Elke keer het 'n bepaalde leerstelling die kenmerkende fokuspunt van 'n spesifieke periode geword. Dit bring verdieping en ontwikkeling van die opeenvolgende leerstellings mee, en elke verdieping en ontwikkeling raak telkens tog ook noodwendig die geheel van die kerk se verstaan van geloof en Skrif. Met verskillende fokuspunte aan die orde, beweeg die Vroeë Kerk kronologies deur die stadiums van die ontwikkeling van die Godsleer en Triniteit, die Christologie, daarna die leer oor sonde en genade, en dan die sakramentsleer. Maar, die parameters van die Apostoliese tradisie word nie prysgegee nie. Die Middeleeue bring afwykings van die Apostoliese tradisie, en dit sou uiteindelik antwoorde in die toekoms afdwing. Die sestiende eeu se Kerkhervorming bring die verwagte konfrontasie. Die Reformasie reageer baie sterk met die regverdigingsleer, en daarmee veral as regstelling van die verkeerde interpretasies wat gevolg het op Augustinus se leer oor sonde en genade en ook die sakramentsleer. Die hart van die Reformasie was inderdaad geleë in die regverdigingsleer (vgl. Lohse 1985:158; Labuschagne 2009:2 van 8). In sy Institusie (Boek III, Hoofstuk XI) verduidelik Calvin (1964a) dit so:

The doctrine of Justification ... is the principal ground on which religion must be supported, so it requires greater care and attention. For unless you understand first of all what your position is before God, and what the judgement which he passes upon you, you have no foundation on which your salvation can be laid, or on which piety towards God can be reared. The necessity of thoroughly understanding this subject will become more apparent as we proceed with it. (bl. 37)

Daarmee is die regverdigingsleer ' $n$ hermeneutiese sleutel tot die verstaan van die Reformasie se geloof en benadering van die Skrif. Die Reformasie moes antwoorde bied op die Middeleeuse mens in die soeke na verlossing en versoening voor God, juis dit waarin die Middeleeuse kerk in gebreke gebly het. Die Reformasie reageer dus nou op:

$[A]$ deficiency in the theology of Scholasticism and of the entire medieval church. The church was unable to satisfy man's desire for genuine assurance of salvation ... According to Catholic teaching then and now, man's justification depends in part on a righteousness to be found in man, and for this righteousness works are of great significance. (Lohse 1985:159)

Hierteenoor stel die Reformasie dat die mens geen bydrae kan lewer tot sy eie saligheid nie. Die verlossing is geleë op 'n ander weg: Die weg van die regverdiging deur die geloof (as gawe van God) wat gerig is op Christus en sy genadige verlossingswerk (vgl. Lohse 1985:160-164).

To have faith means not to trust in our own works, but humbly and gratefully to take the hand of God which reaches out to us. It means to trust and love God as a child its father. (bl. 161,162)

Wanneer Adolf von Harnack (1851-1930) oordeel dat die Reformasie 'n einde gebring het aan die kerklike dogmas, en dan modern sou kon voorkom, is hy slegs gedeeltelik korrek, in die sin dat die Reformasie wel nie die Roomse beskouing gedeel het dat die kerklike leerstellings onfeilbare proposisies was nie. Maar Von Harnack bly uiteindelik in gebreke wanneer hy nie besef nie dat vir die Reformasie die kerklike leerstellings nogtans belangrik is in terme van uitdrukking van die kerk se geloof, as konfessies van die kerk. Vir Ernst Troeltsch (1865-1923) het die moderne era nog nie vir die Reformasie deurgebreek nie, omdat die Reformasie in die verstaan van die Bybel en die Woord van God nog verbind was aan 'n objektiewe realiteit buite die bewussyn van die mens, vir Troeltsch vergelykbaar met die Middeleeue wat verbind was aan 'n verobjektivering van sakramente en dogmas (vgl. Lohse1985:157, 158).

Teenoor die Middeleeuse kerklike tradisie het die Reformasie met Sola Scriptura die Bybel as die hoogste gesagsbron vir leer en lewe gestel, en die Bybel is Christosentries (Solus Christus) en histories letterlik geïnterpreteer (vgl. Labuschagne 2001:974-975). Dit beteken wel nie dat die kerklike belydenis nie gesag gedra het nie; die Skrif is beskou as norma normans, die hoogste norm, en daarteenoor is die kerklike belydenis gesien as norma normata, die norm met afgeleide gesag, afgelei van die Skrif (vgl. Botha 1997:1294-1295).

Die relasie met Christus (die Woord van God wat mens geword het, en die waarheid wat in Hom vergestalt [Joh 1:1, 14; 14:6]) vervaag tog ietwat, wanneer D.J. Smit (1998) dit hermeneuties so sien dat die Reformasie 'n selfgenoegsaamheid aan die Skrif toeken:

The idea of the sufficiency of the Bible was to become a hallmark of the Reformation ... [T] he Word itself was powerful, was convincing readers and listeners, was giving its own spiritual testimony, was self-authenticating and was the Word of God itself, powerful unto salvation. And they no longer needed the church and its Tradition. (bl. 289)

\section{Post-Reformasie: Protestantse skolastiek en piëtisme: 1600-1800}

Karl Barth (1886-1968) het so vele maal gesê: Jesus Christus alleen is die Woord van God. In sy Kerklike Dogmatiek I, 1 sê Barth (2008:137) in twee gedeeltes van die Here Christus: 'From Him alone it may and will be experienced what the Word of God is.' En sy verduideliking, met sy kenmerkende geladenheid van elke woord (met die klem op God se openbaring in Christus as 'the Word ... in its identity with God'):

Understanding the Word of God not as proclamation and Scripture alone but as God's revelation in proclamation and Scripture, we must understand it in its identity with God 
Himself. God's revelation is Jesus Christ, the Son of God. (Barth 2008:137; vgl. ook bl. 153)

Dit maak die relasie met Jesus Christus, die Here, baie belangrik. Emil Brunner (1889-1966) (1964) skrywe, baie treffend, by geleentheid so oor God se Woord en die relasie met Christus, mensewoorde en waarheid:

$[W]$ e can now also understand why and how far the Bible is called God's Word. The true Word of God is not the Bible but Jesus Christ. Christus rex et dominus scripturae. The reformer Luther opposes all dead literalism with 'What deals with Christ, that is apostolic'; that is at stake. Not a separation between the two, but a clear and unambiguous subordination is made. We have not faith in a book, but faith in a Person. It is not the book that is our authority, but a Person; Christ himself is the Word. (bl. 23, 24)

But the book is the witness to this person, the witness to the Word that he is and will bestow upon us. In the Bible the fact and the person Jesus Christ is offered to us as word in the grammatical sense, as a report and as teaching. (bl. 24)

The Bible is the original record that bears witness to the Word that is Jesus Christ as a historical phenomenon ... The Bible is divine truth because and in so far as it bears witness to Jesus Christ and shows him to us ... Our faith is therefore related to this Word in the Bible, not to the Bible as such ... [W]e do not have the Word of God in Holy Scripture in such a way that it is at our disposal, but in such a way that we must repeatedly seek for it in Scripture. And we possess it only in so far as it possesses $u s$, not our understanding, our knowledge, our thought merely, but our person. (bl. 24)

Wanneer die geneigdheid nou anders ontwikkel, om te veel te maak van menslike woorde en insigte, om sodoende waarheid in begrippe en formulerings te probeer vasvang en te verselfstandig, vervaag die heenwysing na en relasie met Christus (die Woord van God) wat die waarheid is. En juis dit gebeur, na die periode van die Reformasie, wanneer byvoorbeeld, die Protestantse skolastiek in die post-Reformasie periode die waarheid in leerstellige proposisies verselfstandig. Dit lei dus tot 'n proposisionele waarheidsbegrip. Geloof word nou grootliks 'n intellektuele oefening en word dan vasgevang in leerstellige proposisies, met dikwels nie veel uitwerking op die lewe van die Christen nie.

Die reaksie op die Protestantse skolastiek, staan bekend as die piëtisme. Die piëtisme begin in Duitsland by Philip Jacob Spener (1635-1705), en versprei vandaar in WesEuropa. In Engeland word dit bekend as Metodisme, veral vanweë die invloed van John Wesley (1703-1791). In Noord-Amerika is dit Jonathan Edwards (1703-1758) wat die piëtisme bekend laat word (Klein, Blomberg \& Hubbard 1993:42).

Die piëtisme benader die Bybel op fundamentalistiese wyse, sodat hulle die Woord van God en mensewoord met mekaar identifiseer. Die gevoel en belewing van die vroom en bekeerde mens neem 'n sentrale posisie in volgens hulle verstaan van geloof. John Wesley vertel van sy eie bekering wat plaasvind op 24 Mei 1738, om kwart voor nege die aand na 'n byeenkoms in Londen waartydens hy geluister het na 'n voorlesing van Luther se voorrede op die Brief aan die Romeine (Bakhuizen van den Brink \& Dankbaar 1968). Wesley vertel so:

I felt my heart strangely warmed. I felt I did trust in Christ, Christ alone for salvation; and an assurance was given me that He had taken away my sins, even mine, and then I testified openly to all there what I now first felt in my heart. (Bakhuizen van den Brink \& Dankbaar 1968:44)

Verder, vanuit die gees van die Renaissance, volg in die sewentiende en agtiende eeu die filosofie van die rasionalisme:

Rationalism regarded the human mind as an independent authority capable of determining truth. In the seventeenth and eighteenth centuries thinkers applied this tool of reason not only against the authority of the Church but also against the Bible itself. (Klein et al. 1993:43)

In alles rakende die religie, wil die rasionalisme die hoogste gesag toeken aan die menslike rede, en:

$[W]$ hereas Aquinas had sought the integration of philosophy and theology, the rationalists promoted the radical divorce of each from the other. (Klein et al. 1993:43)

In meer ortodokse kringe word die Skrif deurgaans histories letterlik geïnterpreteer. Die Reformasie se uitgangspunte het vervaag, sodat selfs die regverdigingsleer prominensie verloor en plek maak vir die leer oor die uitverkiesing, soos by Theodorus Beza (1519-1605) en in die Dordtse Leerreëls van 1618-1619 (vgl. McGrath 2005:465-469). Die Apostoliese tradisie vervaag in hierdie periode.

\section{Die negentiende eeu se dualisme in die moderne en postmoderne periode: 1800-2000: Geloof en geskiedenis}

In die negentiende en twintigste eeu vervaag die Apostoliese tradisie in kringe sterk beïnvloed deur die kontemporêre filosofie. Die dualisme van die negentiende eeu se filosofie, met sy twee konfronterende wêrelde van die empiriese en spirituele, domineer die filosofiese en teologiese debat in die moderne en postmoderne periode (negentiende en twintigste eeu). Die dualisme-denke raak uiteindelik ook die verstaan van Skrif en geloof.

Sedert die begin van die negentiende eeu het die vraag oor die interpretasie van die Skrif en daarmee saam, die vraag na die verstaan van geloof, in sy kern te doen met die verhouding tussen geloof en geskiedenis. Geloof en geskiedenis word nou die sentrale tema van die teologiese debat. Hierdie belangrike teologiese debat loop oor na die twintigste en een en twintigste eeu. Dit beteken die groot vraag gaan in hierdie periode oor die agtergrond wat geloof in die geskiedenis het. En vir sommige is die vraag selfs of geloof wel hoegenaamd 'n agtergrond in die geskiedenis het.

Die negentiende eeu se dualisme dui hermeneuties op twee ekstreme wêrelde wat teenoor mekaar staan. 
Aan die een kant vind ons die verobjektivering van dit wat wetenskaplik ondersoek word, en dit dui op 'n isolering van die objek van ondersoek. Alles word klinies as objekte hanteer, ook die spirituele en die mens se diepste en intiemste emosies. 'n Wêreld anderkant die materiële en liggaamlike word eenvoudig uitgeskakel. Vir baie beteken dit dat die geestelike en die eksistensieel menslike ervaring virtueel nie vir die negentiende eeu se modernisme bestaan nie:

Modernism sees humans, and then not only their bodies but also their minds and entire spiritual life, as an object to the methods of the natural sciences. Within the reach of bare factuality, people are seen as being integrally part of the whole of the natural world ... as most essentially controlled and guided by natural laws. (Labuschagne 2013:5)

Die histories kritiese metode, in die teologiese wêreld (wat geen ruimte bied vir openbaring of enige bonatuurlike intervensie of verstaan nie), dink vanuit hierdie dampkring in byvoorbeeld hulle historiese Jesus-ondersoek.

Aan die anderkant vind ons, teenoor die modernisme en verobjektivering, weer 'n versubjektivering in die verstaanprosesse, en dit beteken 'n isolering van die subjektiewe menslike bewussyn. Wat ontbreek, is die interaksie met die omwêreld.

Teen hierdie agtergrond, van die negentiende eeu se dualisme met sy twee ekstreme beskouings van verobjektivering en versubjektivering wat teenoor mekaar staan, lei die modernisme dan na die historiese kritiek - wat werk met die volgende filosofiese vooronderstellings (vgl. Klein et al. 1993:44; Rasker 1986:213-216):

- Eerstens, die menslike rede was die maatstaf vir beoordeling van die Bybel en geloof, sonder ruimte vir bonatuurlike intervensie (sonder wonders, openbaring, ensovoorts). Die Bybel word soos enige ander boek ondersoek.

- Tweedens word 'n naturalistiese wêreldverstaan gehandhaaf in die verklaring van alles volgens die verloop van oorsake en gevolge. So gesien, word die historiese gesien in terme van korrelasie en 'n ontwikkelingsproses (in die sin van 'n evolusionêre proses).

- Derdens word gewerk met tydsgebonde waarhede, sodat die Bybel se waarhede gevolglik gereduseer word tot dit wat gedateer is, tot slegs wat mense gedink het binne ' $n$ bepaalde tydsraamwerk. Die verlede, ook in die Bybel, word nou maklik gedegradeer tot premodern en prewetenskaplik, en nie werklik geëvalueer vir dit waarvoor dit werklik staan nie.

As respons op die opkomende natuurwetenskaplike metode en die impak van Isaac Newton (1642-1727) se fisika, met daarby die invloed van die filosofie van die Engelse empirisme, volg die filosofie van Immanuel Kant (1724-1804) - grondlegger van die moderne kritiese filosofie. Kant se filosofie het ingrypende invloed vir sy tyd en daarna. Kant se kritiese filosofie wil die menslike rede daartoe lei om die uitdaging te aanvaar sodat die menslike rede sigself ondersoek vir sy eie gronde, moontlikhede en beperkinge. Kant dink dualisties, en onderskei tussen teoretiese rede en praktiese rede. In terme van sy teoretiese rede leer Kant vervolgens dat alle wetenskaplike kennis wat die vertrekpunt neem vanuit die objektief waarneembare wêreld, nogtans afhanklik is van die menslike verstandsfunksies. Uit die menslike bewussyn se intellektuele aktiwiteit (om te dink in terme van 'Kategorien') en die bewussyn se vermoë (om te verstaan onder die twee waarnemingsvorme ['Anschauungsformen'] van ruimte en tyd) word vorm gegee aan dit wat objektief aangebied word deur waarneming en ervaring. Kant wil hiermee uitdruklik leer dat in die versameling van wetenskaplike kennis, afgesien van kennis se objektiewe vertrekpunt, daar tog ook in die kennisproses 'n geheel subjektiewe bydrae (a priori) gemaak word deur die menslike bewussyn. Kant het onwrikbaar vasgehou aan sy oortuiging dat alle wetenskaplike kennis die oorsprong het in 'n objektiewe basis, en daarmee het hy geleer dat die menslike bewussyn, met sy teoretiese rede, nie in staat was nie tot wetenskaplike kennis van die drie sentrale gedagtes van die tradisionele metafisika, naamlik: God, vryheid en onsterflikheid. Kant het met sy nuwe denke die tradisionele metafisika en natuurlike teologie' $n$ hewige slag toegedien. Selfs die tradisionele teologiese denke was nie onaangeroer nie. Tog was Kant oortuig van 'n uitweg: God, vryheid en onsterflikheid kon wel in terme van die teoretiese rede nie wetenskaplik bewys word nie, maar in terme van die menslike bewussyn se praktiese rede was God, vryheid en onsterflikheid wel essensiële vooronderstellings. Kant se subjektiewe oortuigings kom nou na vore, en daarin het die outonome menslike bewussyn basies die laaste sê: Vir Kant is die mens vry om te leef volgens die diktaat en die outonomie van sy eie rede en bewussyn. Religieuse en spirituele oortuigings is vir hom iets van die menslike bewussyn, en vir hom het dit daarvolgens alleen beweegruimte binne die grense van die menslike rede, en wel op basis van die menslike moraliteit. Religie maak vir Kant alleen sin in diensbaarheid aan die moraliteit. Kant (1974) redeneer vanuit sy dualisme-denke dan so:

A Supreme Being is, therefore, for the speculative reason, a mere ideal ... the objective reality of which can neither be proved nor disproved by pure reason. (bl. 372)

Now I maintain that all attempts of reason to establish a theology by aid of speculation alone are fruitless, that the principles of reason as applied to nature do not conduct us to any theological truths, and, consequently, that a rational theology can have no existence, unless it is founded upon the laws of morality. (bl. 370)

Kant is oortuig dat elke mens in sy gemoed ' $n$ argetipe het van 'n lewe wat vir God welbehaaglik is; dat die argetipe alreeds teenwoordig is in die menslike rede; dat mens daarom nie ' $n$ historiese Jesus nodig het om die weg te wys nie; en dat enigiets wat meer sou vra, destruktief sal wees vir die outonomie van die menslike moraliteit, en vir die mens as redelike wese (vgl. Macquarrie 2003:180-191). 'Kant, it will be remembered, singled out human autonomy as the central significance of the Enlightenment' (Macquarrie 2003:360). Rasionele denke, in terme van die praktiese rede, lei Kant daartoe om te leer dat morele essensie iets is wat die mens kan aflei van rasionele prinsipes alleen, deur middel van die mens se a priori denkvermoë. Met sy verstaan van die praktiese rede verwag Kant van die rasionele filosoof en die 
rasionele teoloog om hulle gevolglik te weerhou daarvan om historiese materiaal in berekening te bring en hulle ten doel te stel om ' $n$ tydlose essensie te ekstraheer vanuit die tradisionele denke, en daaruit die morele betekenis vas te stel. Hierop reageer John Macquarrie (2003:177) krities as volg: '[E]ven as sober a man as Kant was swept to the extravagant view that reason can operate in a vacuum, without regard to history and circumstance.' En:

Could one possibly arrive at the 'essence' of Christianity or of any concrete form of religion by abstracting it from its history and its symbols, as if these were somehow extraneous additions? (bl. 177)

In sy moraliteitsdenke gebruik Kant die woord postulaat vir dit wat hy as absoluut noodsaaklik en waar aanvaar, kragtens sy outonome menslike bewussyn (rede). Hy onderskei kragtens sy praktiese rede drie postulate: God, vryheid en onsterflikheid. Op basis van die mens se morele ervaring, leer Kant nou vervolgens, dat dit moontlik was om die beperkinge te deurbreek na die spirituele realiteit (vgl. Macquarrie 2003:252). Hy ontleed die morele ervaring, in kort, as volg:

Vir Kant is die menslike gewete 'n gegewe werklikheid. Nou volg die drie postulate as noodsaaklikhede vir die moraliteit. In die menslike gewete is dit sy pligsbesef, met sy kategoriese imperatief, wat ons oortuig van ons menslike vryheid (postulaat) om in staat te wees tot morele optrede. Deug en geluk, wat vir 'n mens belangrik is in ons huidige wêreld, vereis egter 'n toekomstige beloning van onsterflikheid (postulaat) vir 'n deugsame lewe. God (postulaat) word nou nodig om hierdie toekomstige onsterflikheid moontlik te maak (vgl. Kuypers 1966:91-93).

Die Kantiaanse filosofie het 'n beduidende rol gehad in teologiese denke wat in die menslike bewussyn die laaste grond vir hulle oortuigings gesien het, en wat gevolglik die weg gevolg het van 'n spiritualiteit ontoeganklik vir die historiese wetenskap. Hieronder tel die teologie van Schleiermacher, Bultmann en Tillich en diegene rondom hulle. Kant se filosofie het welkome ontsnaproetes aangebied ten opsigte van die potensieel destruktiewe implikasies van die historiese kritiek (sedert die negentiende eeu), vir 'n geloof gebou op die kerugma van die Skrif. Dit het hy gedoen deur geloof en religie te onttrek uit die wêreld van die teoretiese rede en daarvoor ruimte te maak in die wêreld van die praktiese rede - wanneer hy 'n enkel subjektiewe basis aan geloof en religie (in die menslike bewussyn) toebedeel, wat vir die historiese navorsing en kritiek ontoeganklik is. Losgemaak van 'n objektiewe begronding, word geloof en religie hiermee geheel vergeestelik (verspiritualiseer), vasgevang in die menslike bewussyn (se ervaring en/of konsepte). Hierdie soort geloof, religie, of teologie hanteer Kant (1974) onder die begrip transendentale teologie:

Transcendental theology aims either at inferring the existence of a Supreme Being from a general experience - without any closer reference to the world to which this experience belongs ... or it endeavours to cognize the existence of such a being, through mere conceptions, without the aid of experience. (bl. 367)
Eberhard Busch (2010:196), hierteenoor, beklemtoon dat indien ons byvoorbeeld van die gebeure van die kruis en opstanding van Christus alleen 'n idee sou maak, ons die werklike Christus nie meer nodig sou hê nie en ons dan volledig op ons eie sou wees, en in die leegheid sou intree.

Die groter geheel van evangeliesgesinde Christene staan in die negentiende eeu, nietemin, steeds buite die wending van enersyds kerklosheid en andersyds die meer filosofies ingestelde benadering. Die negentiende eeu is buitendien die eeu van enorme groei in die Christendom vanuit die uitgebreide sendingwerk in hierdie periode - en waarin die Calvinisme ook 'n beduidende aandeel gehad het (vgl. Labuschagne 2009:482).

\section{Drie hoofstrome van hermeneutiese uitgangspunte}

Daar bestaan uiteindelik drie hoofstrome van hermeneutiese uitgangspunte waarvan ons kennis neem (met uiteraard grys areas tussenin), veral sedert die aanvang van die debat oor die verhouding tussen geloof en geskiedenis:

1. Geloof het 'n agtergrond in die geskiedenis: Die eerste hoofstroom leer dat geloof 'n agtergrond het in die werklikheid van dinge wat in die geskiedenis plaasgevind het, en leer ' $n$ identiteit tussen woord van die mens en Woord van God in die Bybel. Hierdie identiteitvasstelling maak dit makliker om te praat van die Bybel as onfeilbare Woord, geïnspireer deur die Heilige Gees, en daar is soms selfs gepraat in terme van verbale inspirasie. Die ervaring van 'n persoonlike bekering word soms sterk beklemtoon. Die strewe na duidelike en sigbare en vaste aanduidings van sekerheid, selfs ' $n$ teken, is opvallend. Soms word na hierdie benadering verwys as fundamentalisties. Dis jammer dat mense soms die woord fundamentalisties in 'n neerhalende sin teenoor mede-Christene gebruik wanneer, onder andere, na oorvereenvoudiging verwys word. 'n Opreg kinderlike geloof moet nie onderskat word in die lig van die Here Jesus se woorde in Markus 10:13-16 nie. Daar moet ook onthou word dat die groot sendingpoging in die negentiende eeu, gepaardgaande met 'n geweldige uitbreiding van die Christelike geloof, vanuit hierdie geloofsverstaan gekom het. Hoewel hierdie groep veral met die piëtisme verbind kan word, is die groep veel groter, omdat die oorgrote meerderheid Christene in elk geval in hierdie kategorie dink en prakties hulle Christenskap uitlewe. Daarmee is nie gesê dat daar nie ook kritiek uitgespreek kan word ten opsigte van hierdie groep nie. In mindere of meerdere mate is nie een van die drie groepe vry van kritiek nie - dis nou eenmaal nie die mens beskore nie.

2. Geloof het nie 'n agtergrond in die geskiedenis nie: Die tweede hoofstroom dink geheel subjektief en leer daarvolgens dat geloof ontoeganklik is vir historiese ondersoek. Geloof het nie sy agtergrond in die werklikheid van objektiewe gebeure in die geskiedenis nie, maar dit moet subjektief begrond word 
(eksistensieel verstaan word), vanuit hoe die menslike bewussyn sy wêreld en homself verstaan. In kort: Hermeneuties lê die laaste grond vir ons verstaan in die mens self, in sy bewussyn. Binne hierdie hoofstroom het die kontemporêre filosofie ' $n$ sterk aanduibare invloed op die kerk se geskiedenis: In die tyd van die Vroeë Kerk was dit die neo-Platonisme wat lei tot 'n verloregaan van die mensheid van Christus in sy Godheid, en sedert die negentiende eeu (met die invloed van die filosofie van Kant en in die twintigste eeu Heidegger, daarna postmodernisme) is dit nou weer net andersom - die Godheid verdwyn in die mensheid. In hierdie denke is daar in die Bybel nie 'n identiteit tussen mensewoord en God se Woord nie; die Bybel is eenvoudig mensewoorde. Met die sterk klem op die uitdrukking en verbeelding van verstaan vanuit die menslike bewussyn (dus selfverstaan volgens Bultmann, en dit geld dan ook ten opsigte van wat die verskillende outeurs skrywe in die boeke van die Bybel) word die Bybel se verhale simbolies en spiritueel verklaar, in terme van metafore en selfs mitologie, en nie as werklike gebeure nie. Hierdie groep vermy 'ontologiese' uitsprake - vermy dus om oor die wese van bestaan uitsprake te maak. Die aandag is eerder gerig op die 'eksistensiële' - die innerlike van die menslike bewussyn en sy ervaringe.

Met die hermeneutiese vertrekpunt van die subjektiewe menslike bewussyn, leer Bultmann (1884-1976) dat God nie sigbaar is buite die geloof nie, maar, dan sê Bultmann ook dat daar nou nie daarvan afgelei kan word dat God nie bestaan buite die geloof nie (Bultmann 1989:114). Nogtans stel hy: 'Certainly, faith in its relation to its object is not provable' (Bultmann 1989:114). En: 'God's word is hidden in scripture just as any act of God is hidden' (Bultmann 1989). In terme van 'existential selfunderstanding' verduidelik hy dat:

[T] he act of God is not visible within the world and cannot be proved, ... the 'salvation occurrence' is not a process that can be objectively established, ... it may also be said that faith is a new understanding of existence or that God's act gives us a new self-understanding. (bl. 115)

Hoe ons dan oor God kan praat, verduidelik Bultmann (1989) so:

[T] hat we can talk about God's act only if we at the same time talk about our own existence, so that God's act cannot be established outside of our own being affected by it, and hence is lacking in the kind of objectivity that can be established by neutral observation (as in an experiment, say) and scientific thinking (precisely as objectifying thinking) ... But if human being is understood as in a genuine sense historical being, which has its experiences in its encounters with others, two things are clear: on the one hand, the faith that talks of the act of God encountering it cannot defend itself against the charge of being an illusion - for the encounter with God is not objective in the sense of a worldly event; on the other hand, faith as an existential process of encounter ... has no need to refute this charge but also cannot ... without misunderstanding its own meaning as faith. (bl. 113, 114)
Die beweging binne Kant se parameters is duidelik. Die Eksistensie Filosofie van Martin Heidegger is ook opsigtelik.

Ook Paul Tillich (1886-1965) is binne hierdie hoofstroming te verstaan. Wat uitdruklik oorkom moet word, volgens Tillich, is alle vorme van ' $n$ teïstiese verstaan van God - wat oorkom moet word is spesifiek die 'theistic objectivation of a God who is a being. ... for ... such a God has disappeared in the abyss of meaninglessness' (Tillich 1974:180). Met 'die God wat verskyn' bedoel Tillich daardie verstaan van God wat 'n teïstiese verstaan uitskakel en dus nie neerkom op 'n persoonlike ontmoeting met 'n persoonlike God as 'n spesifieke wese nie:

The God above the God of theism is present, although hidden, in every divine-human encounter. Biblical religion as well as Protestant theology are aware of the paradoxical character of this encounter. They are aware that if God encounters man God is neither object nor subject and is therefore above the scheme into which theism has forced him. They are aware that personalism with respect to God is balanced by a trans-personal presence of the divine. They are aware that forgiveness can be accepted only if the power of acceptance is effective in man - biblically speaking, if the power of grace is effective in man. They are aware of the paradoxical character of every prayer, of speaking to somebody to whom you cannot speak because he is not 'somebody', of asking somebody of whom you cannot ask anything because he gives or gives not before you ask, of saying 'thou' to somebody who is nearer to the I than the I is to itself. Each of these paradoxes drives the religious consciousness towards a God above the God of theism. (Tillich 1974:180, 181)

3. Geloof het, in'nkomplekser sin (as by die eerste groep), wel 'n agtergrond in die geskiedenis: Die derde hoofstroom leer ook dat geloof 'n agtergrond het in die werklikheid van dinge wat in die geskiedenis plaasgevind het (bv. die kruis en opstanding van Jesus Christus). Sommige teoloë binne die tweede en derde hoofstroom maak, sedert Martin Kähler (1835-1912) wat val binne die derde hoofstroom,'n onderskeid tussen 'Historie' en 'Geschichte' om te verwys enersyds na historie as wetenskap en andersyds na geskiedenis as beriggewing van die verlede, soos deur gewone mense of dan op 'n wyse wat die gewone wetenskaplike metode oorskry. Die derde hoofstroom leer nie identiteit nie, maar relasie tussen die Woord van God en die mensgeskrewe woorde in die Bybel. Die Bybel se woorde is alleen in relasie tot Jesus Christus te verstaan as die Woord van God, en word God se Woord in gelowiges se harte deur die Heilige Gees. Die Drie-enige God alleen is in beheer van sy Woord. Die deurslaggewende hermeneutiese vertrekpunt by hierdie groep is uitdruklik geleë, nie in 'n aanvaarding van die laaste grond in die menslike bewussyn nie (in filosofiese $\sin$ ), maar in die selfopenbaring van God in Jesus Christus (in die geskiedenis). Die geskiedenis is die 'locus' [die plek] van die openbaring. Wat dus beklemtoon word, is die selfopenbaring van God in Jesus Christus. Die inisiatief en moontlikheid om ontmoeting te skep tussen God en mens bestaan volledig en alleen in die hande van 
die Drie-enige God. Die menslike onvermoë om God te bereik, vanuit die menslike bewussyn of watter kapasiteit van die mens dan ook al, word beklemtoon. Wat ons vanuit die geloofsontmoeting waag om te sê, kan hoe belangrik wees en steeds weer en weer bely word, en dit hoort ook so, maar die menslike woord kan nogtans nooit ' $n$ finale woord wees nie. Die gelowige se menslike woord, kerklike leerstelling, belydenis, ensovoorts, kan nooit meer wees nie as om te wys in die rigting van God se waarheid in Jesus Christus. Die finale woord bestaan alleen vanuit God self, en daardie Woord kom tot ons in Jesus Christus - God wat in menslike gestalte tot ons toetree. Daardie Woord word in ons harte en lewens bevestig deur die Heilige Gees. Van God wat ons ontmoet deur sy Woord lewer die Bybel getuienis. Die Bybel se woord word eers deur die Heilige Gees God se Woord in die harte van gelowiges. Hierdie evangelie word deur die kerk deur die eeue oorgedra van geslag tot geslag - en die roeping bly om dit oor te dra soos dit van die apostels ontvang is, dit wil sê, in die Apostoliese tradisie. Die eerste en die derde hoofstrome het nie werklik 'n stryd met mekaar nie.

Karl Barth dink hermeneuties binne die raamwerk van die derde hoofstroom, anders as Bultmann. Rudolf Bultmann (1993:57), in sy interpretasie van die Paasgeloof, weerhou hom uitdruklik van enige verwysings na die werklikheid van gebeure in die verlede, van 'tangible demonstrations', en in die Paasverhale sien hy ook nie 'more than they are able to be: signs and pictures of the Easter faith.' In sy response hierop, verwerp Karl Barth 'n suiwer geestelike (of simboliese) verstaan van die opstandingsgebeure. Die voorstellings van die menslike bewussyn se inherente verstaan van die menslike eksistensie en van geloof, sonder die determinerende impak van 'n eksterne realiteit en gebeure, is vir Barth nie aanvaarbaar nie. Daarby kan God ook nie, vir Barth se verstaan, produk wees van die immanente (inherente) moontlikheid van die menslike bewussyn nie (vgl. Barth 1964:75-76). Vergelykbaar met die volgorde van die Apostoliese tradisie, moet die Paasgeloof vir Barth in hierdie volgorde verstaan word: Paasgebeure, Paasboodskap, en dan Paasgeloof. Hy aanvaar nie Bultmann se subjektiewe vertrekpunt nie: eers Paasgeloof en dan Paasboodskap, met geen voorafgaande gebeure nie (Barth 1964:76). Barth verduidelik:

Whoever begins with the Easter faith in order to make it the content of the Easter message and finally indulgently to let the Easter event fall away - his talk on the subject is ... certainly not legitimate. (bl. 76)

Barth werk met die belangrike onderskeiding tussen Historie (historie as historiese wetenskap) en Geschichte (werklike gebeure soos ervaar deur gewone mense en deur gewone mense in hulle getuienis bekend gemaak) (Barth 1955:160). Hierdie onderskeiding blyk ook wanneer Barth (1964) verder verduidelik:

$[T]$ he Easter message does in fact not have the character of Historie ... The historian will speak here of saga and legend.
If Bultmann wanted only to say that we are concerned here with history (not myth!) in the form of saga and legend, there could be no objection to him ... The Bible contains innumerable sagas and legends. But it would be false to conclude from this fact that they are not the expression of real happenings. In no case does the Bible intend to present timeless truths or myths. And so also in this case, it intends to be genuine history (Geschichte), but history in a form inaccessible to Historie. (bl. 76)

Loader (1996:583-585) wys op die noue verband tussen die Dialektiese Teologie (van Karl Barth, Emil Brunner e.a.) en die Nederlandse Etiese Teologie (van Daniël Chantepie de la Saussaye, J.J.P. (jr.) Valeton, J.H. Gunning e.a.) en merk dan op:

Die Barthiaanse visie op die openbaring van God in Christus en die getuienis daaraangaande in die proposisies van die Skrif en verkondiging kan as parafrase vir die etiese standpunt gebruik word. Hierin gaan dit om die hart van die Barthiaanse teologie ... [en] van die etiese teologie ... Die dialektiese opvatting dat die begrippe van die Skrif en die verkondiging eers deur die werking van die Heilige Gees God se woord wórd, is goed verbindbaar met die etiese opvatting dat die openbaring nie in begrippe nie, maar in Christus self lê, terwyl die begrippe van die Skrif en verkondiging eers kragtens die ontmoeting met God waar is. ... In sy tipering van JH Gunning sê Miskotte ... treffend: 'de ethische is dialectisch'. (Loader 1996:583)

\section{Die Triniteit as hermeneutiese sleutel}

Die hedendaagse verstaan van die Triniteit, beslis teen die agtergrond van die ekumeniese verstaan daarvan deur die kerk van alle eeue, het ' $n$ beslissende hermeneutiese sleutel geword in die teologie as geheel. Geloof in die Drie-enige God is hiervolgens bepalend vir die geheel van die Christen se lewe. Christoph Schwöbel (2009:25-37) onderskei 'n 'prototrinitarian grammar of Christian discourse on God' in beide Ou en Nuwe Testament. Moltmann (1998) wys op die 'Trinitarian origin of Biblical history':

According to the witness of the New Testament Jesus is manifested as 'the Son'. His history springs from the co-efficacy of the Father, the Son and the Spirit. His history is the history of the reciprocal, changing, and hence living relationship between the Father, the Son and the Spirit. (bl. 64)

For ultimately we must always see to it that the liberating force of the biblical witness is preserved and not obscured. (bl. 65)

Dit geld ook van die Vroeë Kerk. Die Bybel se getuienis oor die handelinge van die Drie-enige God word deur hulle bevestig in die voortgang van die Apostoliese tradisie. Die Niceense Konfessie bevestig die kerk se verstaan van die Triniteit, en verwys na die kerk as uitdruklik 'Apostoliese Kerk' (naas ander belangrike kenmerke van die kerk). Augustinus se verstaan van die Triniteit het sy vertrekpunt in die Niceense geloof, 'in the identical essence of the Father, Son, and Spirit and in their common action' (Letham 2009:50). $\mathrm{Na}$ Augustinus het die verstaan van die Triniteit, en die berekening daarvan in die Westerse teologie, egter op die 
agtergrond begin raak - in die Middeleeue by Thomas Aquinas, en ook by ander figure. Dit word hierna 'n patroon om onder filosofiese druk die Triniteit na die agtergrond te verskuiwe (Letham 2009:45, 46). En hierdie filosofiese druk vererger in die Verligtingstyd wanneer openbaring en bonatuurlike intervensie problematies word. In hierdie gees het Friedrich Schleiermacher (1768-1834) sy hantering van die Triniteit beperk tot 'n appendiks in sy boek oor Die Christelike Geloof (Letham 2009:45).

Teen die tweede helfte van die twintigste eeu was dit egter anders, en dan word weer aangesluit by die Apostoliese tradisie wanneer Karl Barth en Karl Rahner die Triniteit sentraal plaas in die teologiese verstaan, in wat bekend geword het as die 'trinitarian renaissance' (Van den Brink 2009:1). Hermeneuties is dit belangrik wanneer Gijsbert van den Brink (2009) dan aantoon:

This renaissance - or revival ... is not restricted to the doctrine of the Trinity as such, but tends to affect the overall scheme of how Christian theology is being done. (bl. 1-6)

Barth se Trinitariese interpretasie, as oorkoepelende verstaan van die Skrif en die teologie, netsoos in die geval van Augustinus, sê nou op meer uitgebreide wyse wat die Apostoliese tradisie in die Vroeë Kerk tot uitdrukking gebring het in hulle Regula Fidei en Konfessies, en waartoe die kerkvadere in teologiese besinning hulle bydrae gelewer het (cf. Barth 2008:295-333). Barth leer dat die Openbaring van God in Jesus Christus Trinitaries verstaan moet word, en ook die Skrif se boodskap moet Trinitaries verstaan word:

$[W]$ e have to say that in respect of revelation there is a genuine and necessary connexion with the doctrine of the Trinity. (Barth 2008:333)

En:

[T] he biblical doctrine of revelation is implicitly, and in some passages explicitly, a pointer to the doctrine of the Trinity. (Barth 2008:333; cf. bl. 312)

Wat die Trinitariese verstaan betref:

[W]e can and must regard it as a good interpretation of the Bible. (Barth 2008:310)

Daar is tans talle kompromievoorstelle in die ekumeniese debat oor die Triniteitsleer se filioque-klousule. Barth se verdediging van die filioque word deur David Guretzki (2009) so saamgevat:

Barth appealed to the filioque in his doctrine of Creation (CD III) as properly pointing to the Spirit as the ontic ground for a real connection between God and the creature, precisely because the Spirit is antecedently the ontic ground of communion between the Father and his Son, and between the divine and the human in Jesus Christ. The Creator Father unites himself with creation in Jesus Christ in the history of creation by the Holy Spirit - the Holy Spirit who proceeds eternally from Father and Son. (bl. 182)

Stanley J. Grenz beskou (in 2004): '[T]he rebirth of Trinitarian theology ... as one of the most far-reaching theological developments of the century' (Kärkkäinen 2009:7). In aansluiting hierby, is dit hermeneuties baie belangrik wat Kärkkäinen sê in die huidige Trinitariese debat, omdat dit die interpretasie van die geheel van die teologie raak: '[T]he Trinity is the most distinctive feature of the Christian faith' (Kärkkäinen 2009:17). Met verwysing na die bydraes van LaCugna, Moltmann en Pannenberg, wys Kärkkäinen verder daarop dat 'at the heart of the ongoing debate stands the question of the relationship between the economic and the immanent Trinity' (Kärkkäinen 2009:7). Balans is belangrik. Wolfhart Pannenberg (1928-2014) beklemtoon dat God dieselfde is in die verlossingsgeskiedenis (ekonomiese Triniteit) as wat Hy van ewigheid af is (immanente Triniteit). Vir Pannenberg is die eenheid van God verbind aan die werk van die drie persone in die wêreld (ekonomiese Triniteit), en dit verwys dan na God se werk wat eskatologies voltooi sal word, en dit alles gebeur in gebondenheid aan die relasies binne die ewige lewe van die Trinitariese God (immanente Triniteit) (Kärkkäinen 2009:21). Jürgen Moltmann (1926-) beklemtoon dat die Triniteit in die 'economy of salvation' [ekonomiese Triniteit] nie anders kan wees as die Triniteit 'in itself' (immanente Triniteit) nie (Letham 2009:52). Moltmann se sosiale Triniteit werk vanuit die drie Persone van die Triniteit na die eenheid van God, en 'the eschatological consummation is the key to both the unity of the Trinity as well as the way of reconciling the relationship between the economic and the immanent Trinity' (Kärkkäinen 2009:19). Barth (2008) het tevore reeds gesê:

God's triunity is to be found not merely in His revelation but, because in His revelation, in God Himself and in Himself too, so that the Trinity is to be understood as 'immanent' and not just 'economic'. (bl. 333)

Drie definiërende ontwikkelinge in die kontemporêre Trinitariese debat moet verder ook onderskei word, en Kärkkäinen (2009:12-17) noem dit:

- Communion theology - dui op Sosiale Trinitariërs met 'n Koinonia-teologie van 'connectedness rather than isolated individuality', wanneer daar in die twintigste eeu ' $n$ bewuswording van persoonwees in terme van relasionaliteit en kommunale verstaan volg.

- Practical implications of the Doctrine of the Trinity - veral Moltmann se wending tot die sosiale analogie bring nuwe koers in die Trinitariese debat. Die Triniteit het altyd 'n relasie met die Christelike leer sowel as die Christelike lewe in al sy aspekte, soveel so dat Colin Gunton daarop wys dat 'n gebrek aan Trinitariese verstaan lei tot intellectual incoherence and ethical confusion.

- Trinity in context - die teologiese debat in die geskiedenis het nog altyd verloop binne 'n bepaalde konteks, hoewel die gevaar uiteraard bereken moet word dat die konteks nie die teologie se determinerende basis word nie.

\section{Anderkant die dualisme - tweede helfte van die twintigste eeu en begin een en twintigste eeu}

Voor die opkoms van die histories kritiese metode in die negentiende eeu was die toe-eiening van die geloofsinsigte 
en Skrifverstaan van die verlede vir baie veel makliker en logies relevant (vgl. Young 2010:485). In die negentiende eeu plaas die histories kritiese metode, in navolging van die modernisme, alle klem op 'n objektief wetenskaplike benadering van die wêreld, en verloor in die proses die subjektiewe keerkant (van wat nie gemeet, geweeg of deur 'n proef bepaal kan word nie). Teenoor hierdie eensydigheid ontwikkel nou, in navolging van Kant se praktiese rede, 'n poging om te kompenseer - die soeke na die waarheid van die morele en religieuse in die subjektiewe denkwêreld van die mens. Die dualisme is onmiddellik daar: Die objektiewe en subjektiewe staan teenoor mekaar. Maar, in elk geval: 'So the historical method turned out not to bring agreement about objective truth after all' (Young 2010:486). Onsekerheid het posgevat en talle teoloë kon nou nie meer aanvaar waarvan die verlede oortuig was nie:

Eastern theology has always affirmed that all theology is in the Fathers, thus implying that theology is simply exegetical of the patristic material; and Western theology, though somewhat less explicit, has in practice accepted that the doctrinal orthodoxy defined in the patristic texts provides the criteria by which essays in systematic theology are to be judged. Appropriation was unproblematic prior to the rise of the historico-critical method. (Young 2010:485)

Te wyte aan die negentiende eeu se dualisme, in die woorde van Frances Young (2010:486): 'There was now developing a glaring hermeneutical gap.' En (bl. 486): '[T]heologians had forfeited their right to claim that the study of the Fathers could contribute directly to the current theological enterprise.'

Teen die tweede helfte van die twintigste eeu kom leidende teoloë na vore in groeiende getalle, wat die integriteit van die teologie anderkant die grense van die negentiende eeu se dualisme vind - teoloë soos Jürgen Moltmann, Wolfhart Pannenberg, Frances Young, en vele ander. '[N]ew approaches to interpretation enable a greater appreciation of many features of ancient rhetoric in general and early Christian literature in particular' (Young 2010:487). Nuutste ontwikkeling in kritiese teorie en hermeneutiek het wêrelde oopgesluit. Deur die antieke wêreld se outeurs ernstig op te neem, hulle omwêreld in ag te neem en te probeer verstaan, en die verlede (sonder manipulering deur eietydse vooroordele) die geleentheid te bied om sigbaar en hoorbaar te word, word iets van Gadamer se historiese bewussyn en 'n fusie van verstaanshorisonne ' $n$ werklikheid. Dit gebeur wanneer die moed gevind word om jou eie mening binne die risikoveld van kommunikasie met die verlede op die spel te plaas, op te weeg teen ander en die verlede, en dan (op bepaalde punte) ook opreg toe te eien, jou eie te maak wat die teks met sy eie integriteit aan jou wil oordra (vgl. Gadamer 2006:390). Frances Young (2010) verwys in hierdie verband na die Ekumeniese Konsilies en Konfessies van die Vroeë Kerk:

For the doctrinal conclusions of the fourth and fifth centuries have remained the identity-markers of mainstream Christianity, and this was the period through which earlier traditions, whether scriptural or patristic, were transmitted ... [I]f, in the interest of continuity of identity, the old formulae are to be retained, along with respect for the Fathers ... then ways of appropriation need to be considered. (bl. 486-487)

In aansluiting by Young, kan vier belangrike hermeneutiese bendaderings nou onderskei word op die weg van toeeiening van 'n gemeenskaplike waarheid vir die verstaan van geloof en Skrif (vgl. Young 2010:487-493):

1. Betekenis lê in die effek wat 'n teks vir die toekoms het: As antwoord op die histories kritiese metode se herhaaldelike eensydige benadering, word betekenis nou nie so seer gesoek in die agtergrond van 'n teks nie (in die lig van botsende konklusies), maar daar word nou uitgegaan van die benadering van 'meaning is in front of the text, in the effect the text may have in the future' (Young 2010:487). Die hermeneutiese gaping word oorbrug wanneer, in die interaksie tussen outeur en leser ('audience'), die teks se ware en logiese betekenis vir die toekoms raakgesien en toegeëien kan word.

2. Dekonstruksie en die voorsiening van geleenthede tot verstaan: Die soeke na betekenis in die gaping wat die vreemde van die antieke wêreld oplewer vir die verstaan van vandag, vra (in respons op Jacques Derrida se gedagtes van dekonstruksie) nie slegs na aanhoudende dekonstruksie van die betekenis van die teks nie, maar dat die gaping ook positief benader word om so geleenthede te bied (te voorsien) vir alternatiewe lesings wat die verskillende wêrelde nader aan mekaar bring in 'n gemeenskaplike verstaan. Iets hiervan is wel al besef deur die kerkvadere. Beide Origenes en Augustinus het die onderskeid tussen die realiteit aangedui (signified) in Skrifgedeeltes en die tekens (signs) wat in die aanduiding (signification) opgesluit lê (Young 2010:489). In hierdie verband het Gregorius van Nyssa byvoorbeeld, volgehou dat 'n gewone letterlike interpretasie van 'Seun van God' tot verkeerde afleidings sou lei, in watter sin die Here Jesus wel die Seun van God is. Ten spyte daarvan het dit God nogtans behaag om Hom te ontferm oor die mens en juis beperkte mensetaal te gebruik om ons iets van Hom en sy waarheid te leer (Young 2010:489). Met al hulle nadenke en geskrifte staan die kerkvadere nietemin, nederig en sprakeloos voor die misterie van God en weet hulle dat Hy alleen die waarheid ken en ons iets daarvan openbaar. Daarmee kan ons, in ons hedendaagse houding van soms te selfversekerd wees in ons spekulasies, tog iets leer by die kerkvadere en hulle verstaan. Young sê, in respons op ons eietydse dekonstruksiedebat, met reg vanuit die kerkvadere se benadering tot verstaan: 'Postmodernism is both anticipated and challenged' (Young 2010:490).

3. Tipologie as ' $n$ wyse om in een verhaal die model te vind vir 'n ander: Tipologie voorsien ' $n$ weg tot toe-eiening, ' $n$ verklaring en 'n model waarmee vereenselwig kan word. Teenoor vergeesteliking van ' $\mathrm{n}$ teks se betekenis (soos die geval met allegorie, metafore en mites) is tipologie ' $a$ method of interpretation ... more attentive to history' (Young 2010:490). Die kerkvadere se hantering van die Skrif was fundamenteel intertekstueel - Nuwe Testamentiese tekste het voortdurend die $\mathrm{Ou}$ Testament aangehaal, weerspieël of daarna verwys. En tipologie was vir hulle 
in hierdie opsig 'n sleutel tot verstaan van die Christelike lewenswyse van skepping tot eindtyd met, in die kern daarvan, die kruis en opstanding van die Here Jesus Christus. Met die herontdekking van perspektiewe soos tipologie, het literêre kritici soos Northrop Frye die histories kritiese benadering van die Skrif ernstig bevraagteken en teengestaan, en het die intertekstualiteit van die kerkvadere weer opnuut aandag begin ontvang in die soeke na beter verklarings van die Skrif se waarheid (vgl. Young 2010:491).

4. Hermeneutiese verstaan in die lig van sosiale bepaaldheid en die erkenning van andersheid: Die feit dat die antieke gemeenskap vir mense van ons tyd soms totaal vreemd en onbegryplik voorkom, soos aangedui deur postmodernistiese ondersoeke, kan ons nogtans nie laat terugdeins nie van die uitdaging tot kommunikasie en dialoog (wat Gadamer aantoon as die twee verstaanshorisonne van teks en leser). Dit kan ook nie 'n geldige oplossing wees nie om eenvoudig die maklike uitweg te kies en die teks se boodskap uit te wis ten gunste van 'n eietydse wêreldbeeld wat op die teks (metafories) afgedruk word. 'The recognition of otherness and difference is a prerequisite for dialogue' (Young 2010:492). Daar kan gebruike, gewoontes en samelewingstrukture in die antieke wêreld se voorstellings voorkom wat vir ons wêreld uitgedien en onaanvaarbaar is, maar dit moet ons nie weerhou daarvan om belangrike insigte oor ons geloofsverhouding met die lewende God wel raak te sien nie. Die sosiale bepaaldheid en andersheid van die antieke wêreld moet geïdentifiseer word deur noukeurige ondersoek en ontleding van daardie wêreld. Maar dan moet alles nie net verwerp word, omdat dit sogenaamd premodern is nie. Ons moet versigtig wees vir die vooronderstellings wat gekoppel word aan negatiewe begrippe soos premodern en prewetenskaplik, asof daar nie ook hoogs intelligente mense in die verlede was nie. Verdieping in daardie wêreld is om ' $\mathrm{n}$ ander meer positiewe rede belangrik: '[A]ppropriation which results from immersion in the world of the texts so that we can identify continuities and possibilities beyond difference' (Young 2010:493). Dit gaan oor belangrike moontlikhede anderkant die verskille. Daar is ook belangrike insigte uit die verlede wat vandag nog baie belangrik is, en ons moet dit nuut ontdek. 'n Mate van openheid en empatie teenoor andersheid maak deure oop vir kommunikasie en dialoog, en lei ook meermale tot veranderde perspektiewe en verruimde insigte.

Nuutste navorsing en ontdekkings in patristiekstudies, wys nie op 'n dualisme in die tekste en dokumente van die verlede nie, lei ons na anderkant die negentiende eeu se dualisme wanneer iets anders ontdek word. Dit ontdek die interaksie tussen letterlike en simboliese taal in die uitdrukking van betekenis en werklikheid, saam met die interaksie van verskillende kulture (Joodse en Griekse) in ' $n$ simbiose van betekenis, en toon dan aan dat die baie komplekse samestelling van waarheid en werklikheid in die verlede deur dualisme interpretasies verkeerd geïnterpreteer is. Samevattend kan op die volgende gewys word:
It is no longer, as used to be thought by some since the beginning of the $19^{\text {th }}$ century, simply a matter of distinguishing 'literal' meaning from 'symbolic' meaning - 'metaphor' or 'myth'. And the next step was used to be then to get rid of the symbolic world in order to get through to the 'bare factuality' of the real world. New discoveries in patristic studies realize that this is an oversimplification and a detrimental mistake. Recent research has however taught us that both worlds carry important meaning, and that they complement one another (cf. Young 2007:xv, xvi). In spite of the temptation of some scholars of the $19^{\text {th }}$ and $20^{\text {th }}$ centuries to try and explain the resurrection of Christ as something to be understood purely spiritual, new Early Church and patristic studies persistently affirm the 'physical character' of the resurrection of Christ (Young 2007: xv). Symbolic and real worlds should not be separated. In both cases human language speaks from a cultural setting - from which meaning is communicated. Frances Young, in referring to the Early Church's emergence from a world of 'considerable diversity in "Jewishness"' and 'the supposed malign influence of Greek philosophy', emphasizes that 'crosscultural interaction is a very complex business' (Young 2007:xvi). The cultural dressing can therefore not be removed without falsifying the message of the past. (Labuschagne 2014:5)

En:

From latest research on historical methodology and their criticism on the presuppositions of the previous generations, it is no longer so simple, as used to be thought, to distinguish reality and literal meaning from myth, symbol or metaphor. This new shift demands from the researcher, now more than ever, to try and enter the 'world' of those researched, to give those researched the opportunity to state their 'case' or what could be called their case. To imagine that we can easily remove the so-called cultural dressing of symbolic language (according to our biased assessments) in order to get to the real assumed picture, do not uncover the reality of the past. The so-called cultural dressing really provides the well-known concepts of the period to explain a totally new event or matter. (Labuschagne 2014:5; cf. Young 2007: xiv-xvi)

Hedendaagse patristiekstudies wys op 'n interaksie tussen letterlike en simboliese betekenis - teenoor die dualisme denke van die negentiende en twintigste eeu. Young (2002) verduidelik:

$[I] \mathrm{t}$ is simplistic to suggest that in doctrinal debate, or indeed in the Antiochene reaction to Alexandrian allegory, we have a 'reversion' to the literal sense. What we do have is an important stress on the 'reality' of the overarching narrative from creation through fall to incarnation and redemption.

The 'reality' of the oikonomia, God's providential activity with respect to the world, meant that spiritualising away the body, the material world, the 'flesh' of the Christ in the story of his birth, life or passion, or indeed in the Eucharist, had to be deemed heretical. (bl. 296)

So allegory was to be admitted only as figure of speech, and only where the text indicated that this figure of speech was in play... [D]iscerning metaphor or irony does, after all, make a difference to perception of meaning, and scripture has its own 'idioms'. The narrative logic of the story, whether on the large scale or the small scale, was to be preserved ... Indeed, the reading of scripture could not be reduced to mere enjoyment of story or interest in the record of past events, for it was a deadly 
serious business. Its purpose was to understand one's place in the great scheme of things, and to learn how to live and act. (bl. 297)

Waardevol is Moltmann (2000) se insig wat nie vasgevang is binne ' $n$ teenspraak van letterlike en simboliese (metaforiese) taal nie, in sy verwysing na 'historical interlacing':

Metaphors go beyond what is at hand, and reach out in anticipation to the possible future ... In the historical interlacing of present and future we form metaphors of what is to come. (bl. 163)

Moltmann (2000) verval nie in simboliese taal nie. 'n Metafoor is uiteindelik alleen verklarend wanneer nie alles 'n metafoor is nie:

I think it is more correct to call Jesus 'the kingdom of God in person', rather than to make him one parabolic kingdom-of-God event among others. We might say that a metaphor begins to illuminate only if not everything is metaphorical; and so the parables of Jesus too begin to speak only if he himself is not a parable. (bl. 166)

Loader breek ook uit die greep van die dualisme in aansluiting by die Etiese Teologie, en in verwysing na die Dialektiese Teologie. Loader (1996:578) sê van die Etiese Teologie ('de waarheid is ethisch' - met verwysing na die Grieks $\eta \theta 0 \varsigma$, ['wese'] - verwys na die strewe van teoloë om hulle te oriënteer op wat hulle beskou as die wese van die waarheid):

Dit beteken dat die etici, wat Emil Brunner later sou noem die 'Objekt-Subjekt-Gegensatz', oorwin het. Nog die menslike ervaring nog 'n verobjektiveerde 'waarheid' voer die botoon. Die waarheid lê anderkant die teenstelling. (Loader 1996:581)

Die waarheid lê anderkant die oorbeklemtonings van die negentiende eeu se dualisme, anderkant 'n verval in die subjektiewe enersyds of die objektiewe andersyds. Die uitweg van anderkant die dualisme dui op kompleksiteit en die belang van die noodsaaklike interaksie in taal en kulturele verbande. Van geloof se waarheid word iets gevind in die verhouding deur die ontmoetingsgebeure. Hiervan is reeds sprake, nie net in die Etiese Teologie nie, maar ook in die Dialektiese Teologie. Loader (1996) praat tereg van 'n 'vertrouensverhouding met God':

Wanneer dit egter wel gebeur dat die proposisie en die persoon agter die proposisie op dié punt geglo word en hierdie 'voor waar houden' opgeneem word in 'n verhouding van vertroue tussen die gelowige en die openbaarder agter die proposisie, dan het ons ' $n$ intersubjektiewe verhouding tussen ' $n$ inisieerder en' $n$ respondeerder. Dan is die proposisie nie die objek van geloof nie en God is ook nie 'n objek nie, maar' $n$ resiproke verhouding kom tot stand. Geloof is dienooreenkomstig 'n vertrouensoorgawe aan God - geen objektiewe religie nie, maar 'n intersubjektiewe verhouding tussen twee subjekte. (bl. 578)

Die waarheid word anderkant die negentiende eeu se dualisme gesoek. Van de Beek (2012:13) sê: 'De kerk is de gemeenskap van mensen die niet meer aan zichself toebehoren maar aan Christus.' Hy verwys egter, midde die uitdaging van ons tyd, na die noodsaak van 'n 'nuwe reformasie' en die belangrikheid van die Vroeë Kerk - teenoor die hedendaagse uitgerafelde groeperinge van 'skatgrawers':

Er is een nieuwe reformatie nodig, nu niet tegen een onderdrukkend institutioneel systeem zoals in de zestiende eeuw, maar tegende de vrijblijvendheid van de menigte van opinies. Er is geen kerk meer en er is geen kerkelijke theologie meer. Er zijn alleen talloze mensen die iets met Jezus hebben en zich naar believen organiseren ... De remedie kan geen andere zijn dan die van de zestiende eeuw: terug naar de bronnen. Laten we eerst maar eens goed luisteren naar wat er in het begin gezegd is. Waar is het allemaal mee begonnen? Dat staat in de Bijbel, maar die is zoseer de prooi geworden van schatgravers die de hele structuur van het gebouw bedorven hebben voor hun eigen kortzichtige belangen, dat we maar terug moeten naar hen die het gebouw hebben gezien toen het nog nieuw was. Uiteraard hebben ook zij hun eigen perspectieven, maar de eenheid van hun denken gaat hun verscheidenheid ver te bovenin tegenstelling tot wat nu het geval is. (Van de Beek 2012:11)

Die uitdrukking van ons geloofsontmoeting met die lewende Heer as kerkgemeenskap deur die eeue en oor die wêreld heen, word verwoord in ons gesamentlike geloofsbelydenis. Van hierdie gesamentlike geloofsbelydenis sê Van de Beek (2012:370) tereg: 'Het Symbool van Nicea-Constantinopel is als regula fidei van de grote vroeg-kerkelijke concilies het meest gezaghebbende belijdenisgeschrift.' Ander belydenisgeskrifte het 'n verskillende status. Van de Beek (2012:391) beklemtoon ook waar dit in dieper sin vir die kerk om gaan: Dit gaan om 'by Christus' bewaar te bly, en in daardie verband kan 'trou aan die belydenis' alleen wys op 'Hom na wie die belydenis verwys', na sy Woord en waarheid wat bewaar moet word.

\section{Die eenheid van die kerk in die Ekumeniese Verband - Handhawing van die kerk van die apostels}

Van Selms (1952) beklemtoon die apostolisiteit van die kerk as ' $n$ 'attribuut van 'n handeling':

Die Kerk word egter as Kerk herken omdat sy Apostolies is, dit wil sê omdat sy vashou aan die prediking van die apostels. Daar is 'n kontinuïteit in prediking van die dae van die apostels af tot nou toe. (bl. 149)

McGrath (1997) verduidelik die betekenis van die Apostoliese tradisie virvandag, en dan is ditopvallend (soos by Pannenberg 1976:147, 158) dat hy die Apostoliese Geloofsbelydenis in relasie tot die Geloofsbelydenis van Nicea-Konstantinopel (325 en 381) verklaar (McGrath 1997:91-93) - en dit kan ook nie anders nie, in die lig van die ekumeniese status van die Niceense Belydenis (soos dit kortweg genoem word) - as Belydenis wat van die begin af vir die hele (universele) kerk geldig is:

The church is apostolic. In other words, it continues steadfastly in the faith and teaching of the first apostles (Acts 2:42) and gladly accepts the Great Commission entrusted to them (Matthew 28:16-20). The faith and the task of the apostles have become ours. 'The faith that was once for all entrusted to the saints' 
(Jude 3) has now been entrusted to us for a time, before we pass it on to those who will follow us. We, and all other Christians, are stewards of the same gospel once entrusted to the apostles. (McGrath 1997:93)

Moltmann (1998:xiv) plaas die hedendaagse teologiese debat met reg in 'n noodsaaklike ekumeniese verband, en daarmee stem hy ooreen met die Vroeë Kerk se Ekumeniese Konsilies, wanneer hy bevestig: '[T]oday Christian theology has to be developed in ecumenical fellowship (oorspronklike beklemtoning).' En daarmee saam: 'It means no longer thinking contrary to the others, but thinking with them and for them' (Moltmann 1998:xiv).

Die Ekumeniese Beweging van ons tyd is in groeiende mate reeds bewus dat kerkeenheid langs die weg van die Apostoliese tradisie lê, en dat die Geloofsbelydenis van Nicea-Konstantinopel deur die eeue, by uitstek, uitdrukking gee aan daardie geloof - volgens die 'Recommendation' (i) in die Odessa Report 1981 (Link 1985:256).

Die 'Commission on Faith and Order' is 'n studiekommissie van die Wêreldraad van Kerke, en hulle studie van die Apostoliese tradisie en die Geloofsbelydenis van NiceaKonstantinopel, gedoen oor etlike dekades heen, wat ingestel is op die eenheid van die kerk oor die wêreld, stel dit so in hulle jongste edisie:

The creedal statement known as the Nicene-Constantinopolitan... is undoubtedly the best witness to the unity of the churches in the apostolic faith ... It reminds all Christians and all communities of their faith, and links it with the faith of all ages and all places. The churches of the Reformation have included it in their creedal books as a reference text that objectively expresses the faith, making no concessions to religious sentimentality, and drawing directly on Scripture. (bl. xiii)

The Nicene Creed is a conciliar creed which, by its wide reception, became the ecumenical symbol of the unity of the Church in faith. This function of the Nicene Creed as an ecumenical symbol was recognized by Faith and Order as early as Lausanne, 1927. While the so-called Apostles' Creed, which originated from Rome, has been received and used only in the Christian West, the Nicene Creed unites all parts of the Christian Church, East and West. (bl. xxiii)

The Nicene Creed thus serves to indicate whether the faith as set forth in modern situations is the same faith as the one the Church confessed through the centuries. (bl. xxii)

Oor die Apostoliese tradisie se geloofsverstaan word gestel:

Christians are called to manifest the unity they have in Christ by their oneness in the apostolic faith and in the sacramental life. (bl. 76)

The Church is apostolic because everything it confesses about Christ comes from the apostles as witness, whose testimony to the life, death, and resurrection of Jesus Christ has been transmitted by the Holy Scripture. In this continuity the Church recognizes and lives its fundamental identity with the Church of Christ's apostles on which it is built once and for all. (bl. 77)

Where Jesus Christ is, there too is the Church Catholic, in which in all ages the Holy Spirit makes people participants of Christ's life and salvation, without respect of sex, race, and position. (bl. 77)

The apostolicity of the Church is manifested in its faithfulness to the word of God, lived out and witnessed to in the apostolic Tradition, guided by the Holy Spirit throughout the centuries, and expressed in the ecumenical Creed. (bl. 77)

In ecumenical dialogues there is a growing agreement that the apostolicity or apostolic tradition of the Church is broader than the concept of apostolic succession of ministry, which is part and sign of that apostolic tradition which it serves. (bl. 78)

In Vancouver (Canada) in 1983, the sixth assembly of the World Council of Churches strongly affirmed the significance and importance of this study and since 1984 it was steadily implemented. (bl. 95-96)

This seventh printing of Confessing the One Faith ... affirms the central role of the Apostolic Faith itself in the life of the churches today - and in their search for the visible unity of the Church. (Confessing the One Faith 2010:100)

Gefokus op die eskatologie, en daarmee gegrond in die toekoms van God se verlossing in en deur die opstanding van Christus, verduidelik Wolfhart Pannenberg (1976) die apostolisiteit van die kerk so:

It is only as the catholic, universal church that the Christian church can also be apostolic in the sense of the fourth predicate and criterion of the church named in the Nicene Creed ... But the universality of the Church and its faithfulness to its apostolic mission belong together, because the mission of the apostles was directed towards the whole of mankind. (bl. 147)

The criteria of the church's apostolic mission, its unity and its catholicity (or universality) also have their essential foundation in the future salvation of the rule of God, which has already been made available to us in Jesus Christ. For the missionary charge to the apostles, which was the foundation for the church's continuing apostolic mission, rests on the fact that the future salvation of the whole of mankind has already appeared in the history of Jesus and especially in his resurrection from the dead. That is why the church's mission is directed towards all men; and that is why universality is one of its own criteria. (bl. 158)

Dit is ook opvallend dat die teologiese debat, wat teen die einde van die twintigste eeu gevoer word tussen verskillende kerkdenominasies, hou binne die parameters van die Apostoliese tradisie (en die Niceense Belydenis in daardie verband). As voorbeeld kan genoem word:

1. Agreed Statement on the Holy Trinity - A statement of the Reformed-Orthodox dialogue, Kappel, Germany 1992, stating: 'We confess together the evangelical and ancient faith of the catholic church in "the uncreated, consubstantial and coeternal Trinity", promulgated by the councils of Nicea (AD 325) and Constantinople (AD 381)' (Gross 2000:280, 280-287).

2. Agreed Statement on the Christology - A statement of the Reformed-Orthodox dialogue, Limassol, Cyprus 1994, stating: 'In accordance with the Nicene Creed we affirm the basic interconnection between the doctrine of the Trinity and the doctrine of Christ' (Gross 2000:288, 288-291). 
3. Joint Declaration on the Doctrine of Justification A declaration of the Lutheran-Roman Catholic dialogue, Augsburg, Germany 1999, stating: 'The understanding of the doctrine of justification set forth in this declaration shows that a consensus in basic truths of the doctrine of justification exists between Lutherans and Catholics' (Gross 2000:573, 566-573).

\section{Konklusie}

'n Tydsgees is uiteraard altyd tydsgebonde, met 'n beperkte verloop. Ons word almal nietemin blootgestel aan verskillende beïnvloeding van die tydsgees: Enersyds, moontlik die tydsgees se aanmoediging tot verdere insig of, andersyds moontlik selfs die tydsgees se gebondenheid aan die populêr gangbare wat ongesiens verlei tot prysgawe van noukeurigheid, om dan nie verder te kyk as dit wat voorgehou word nie. Wanneer die tydsgees verloop het, mag dit ons laat met 'n ongemaklike gekompromitteerde beeld. Waarheid en werklikheid is immers dikwels ' $n$ baie komplekse aangeleentheid met vele verbandhoudende en groeiende relasies en kontekste. Die historiese navorsing het nou eenmaal die aandrang om met verloop van tyd alle kompleksiteite oop te maak en te ondersoek, opwindende nuwe insigte te vind en openbaar te maak, maar tegelyk ook te manifesteer dat die mode en die golf van die verskillende tye nie noodwendig altyd in toereikende mate iets van die waarheid en werklikheid vergestalt nie dit ontbreek soms selfs aan die nodige metodologiese integriteit. Bewustelike openheid word van die navorser verwag, om die geskiedenis toe te laat om uitdrukking van sigself te gee in die gesprek en kommunikasie van die hede met die verlede.

Hierdie studie gee aanduiding dat die Apostoliese tradisie histories sigbaar geword het as 'n belangrike leidende en voortgaande hermeneutiese sleutel vir die verstaan van die Skrif en die geloofslewe van die een algemene kerk. Die Apostoliese tradisie staan nie teenoor leerstellige konsensus en konfessies (as uitdrukking van sy geloof en lewe) nie, maar wel teenoor filosofiese, skolastiese en ander op hulleself verobjektiveerde verstaansproposisies.

Wat in hierdie navorsing as van kardinale belang vir die hermeneutiese proses uitstaan, midde die kompleksiteit van die talle kontekste, is nie bloot reekse onsamehangende hermeneutiese eilande nie, maar wat wel samehang in die historiese verloop en veral dan in en rondom die sleutelposisie van die Apostoliese tradisie vir die verstaan van geloof en lewe in die kerk deur die eeue. Vir die een heilige, algemene (katolieke) kerk, gegrond op die leer van die apostels, kom die uitdrukking van hierdie geloof en lewe in die kerklike belydenis ekumenies, by uitstek, na vore in die Geloofsbelydenis van Nicea-Konstantinopel (325 en 381). Die uitdrukking van hierdie geloof en lewe, vanuit die ontmoeting met die Drie-enige God, in Christus deur sy Gees, wys terug op die gebeure waarna die Belydenis wys: Die openbaring van God wat Hom in sy Seun (in die menswording van Christus) vereenselwig met die lot van die mensdom en sy ganse skepping, waarvan die Bybel berig gee as primêre geskrewe bron van die kerk. Ontmoeting het uiteindelik so baie te doen met die diepgaande bewuswording van 'n verhouding met die lewende God, in terme van Christelike spiritualiteit - in terme van seeking closeness to God: 'Christian spirituality deals with a relationship - to the triune God we know through Jesus Christ' (Kessler \& Kinnamon 2000:63). 'Christians have relied on a variety of personal and communal ways to seek God, to receive God, and do God's will' (Kessler \& Kinnamon 2000:64). John Macquarrie (1972) sê:

'[S]pirituality'... includes prayer, worship and whatever other practices are associated with the development of the spiritual life ... I believe that fundamentally spirituality has to do with becoming a person in the fullest sense. (bl. 40)

Die Apostoliese Geloofsbelydenis (of Twaalf Artikels) moet by implikasie in relasie tot die Ekumeniese Belydenis van Nicea-Konstantinopel (325 en 381) geïnterpreteer word, soos ook wel reeds gedoen word. As belydenis van die Westerse kerk, en gefinaliseer op 'n veel later datum, het die Apostoliese Geloofsbelydenis ekumenies, nie dieselfde gesag en status nie as die Ekumeniese Belydenis van NiceaKonstantinopel, wat die belydenis is van die hele kerk: Protestants, Rooms en Ortodoks (die kerk van die Weste en die Ooste). Met verwysing na die Niceense Belydenis (325 en 381) bevestig Davies (1995:199): '[T]his statement is the only one which the Church as a whole has ever received.' Die Apostoliese Geloofsbelydenis, met sy oorsprong in 'n basiese Romeinse doopbelydenis (die Romanum - ca. 150), met 'n mate van vastheid teen 340 (in die apologie van Marcellus van Ancyra), ontwikkel deur verskillende wysigings (vgl. Rufinus se Commentarius in symbolum apostolorum - ca. 400) en byvoegings om in die agtste eeu, in Boergondië, die vorm te bereik wat ons vandag het (vgl. Davies 1995:198, 199, 261; Lohse 1985:32-36).

Die ekumeniese strewe tot eenheid van die kerk oor die wêreld en deur die eeue word toenemend vandag veranker in die Apostoliese tradisie. Vir ons verstaan van geloof en die Skrif bly dit, soos vir die universele kerk deur die eeue, baie belangrik. Die hermeneutiese waarde daarvan mag nie onderskat word nie.

\section{Erkenning Mededingende belange}

Die outeur verklaar dat hy geen finansiële of persoonlike verhouding(s) het wat hom op 'n voordelige of nadelige wyse in die skryf van die artikel beïnvloed het nie.

\section{Literatuurverwysings}

Bakhuizen van den Brink, J.N. \& Dankbaar, W.F., 1968, Handboek der kerkgeschiedenis, 4de Deel, Bert Bakker/Daamen N.V., Den Haag.

Barth, K., 1955, Die Kirchliche Dogmatik IV, 2, Die Lehre von der Versöhnung, Evangelischer Verlag, Zürich.

Barth, K., 1964, The Heidelberg Catechism for today, transl. S.C. Guthrie, Epworth Press, London.

Barth, K., 2008, Church dogmatics I, 1, The doctrine of the Word of God, transl. G.W. Bromiley, T\&T Clark, London. 
Bierma, L.D., 2005, 'The purpose and the authorship of the Heidelberg Catechism', in L.D. Bierma (ed.), An introduction to the Heidelberg Catechism - Sources, history and theology, pp. 49-74, Baker Academic, Grand Rapids, MI.

Botha, S.J., 1997, 'Belydenis in kerkregtelike verband met besondere verwysing na die konsep Kerkorde 1997, Nederduitsch Hervormde Kerk van Afrika', HTS Teologiese Studies/Theological Studies 53(4), 1290-1320. http://dx.doi.org/10.4102/hts. v53i4.1793

Brunner, E., 1964, The Word of God and modern man, transl. D. Cairns, John Knox Press, Richmond, VA

Bultmann, R., 1989, New Testament and mythology - and other basic writings, transl. S.M. Ogden, Fortress Press, Philadelphia, PA.

Bultmann, R., 1993, Theology of the New Testament, vol. 1, transl. K. Grobel, SCM Press, London.

Busch, E., 2010, Drawn to freedom - Christian faith today in conversation with the Heidelberg Catechism, transl. W.H. Rader, Wm. B. Eerdmans, Grand Rapids, MI.

Calvin, J., 1964a, Institutes of the Christian Religion, vol. 2, Book Third - The mode of obtaining the grace of Christ. The benefits it confers, and the effects resulting from it, transl. $\mathrm{H}$. Beveridge, $1-276, \mathrm{Wm}$. B. Eerdmans, Grand resulting from
Rapids, MI.

Calvin, J., 1964b, Institutes of the Christian Religion, vol. 2, Book Fourth - Of the holy Catholic Church, transl. H. Beveridge, pp. 277-676, Wm. B. Eerdmans, Grand Rapids, MI.

Confessing the One Faith, 2010, 'An ecumenical explication of the apostolic faith - as it is confessed in the Nicene-Constantinopolitan creed (381)', 7th rev. edn., World Council of Churches Publication, Geneva. (Faith and Order Paper, 153).

Davies, J.G., 1995, The Early Christian Church, Barnes \& Noble Books, New York, NY

Gadamer, H-G., 2006, Truth and method, transl. J. Weinsheimer \& D.G. Marshall, Continuum, London.

Gross, J. (ed.), 2000, Growth in agreement II, World Council of Churches Publications, Geneva.

Guretzki, D., 2009, Karl Barth on the filioque, Ashgate, Burlington.

Kant, I., 1974, Critique of pure reason, transl. J.M.D. Meiklejohn, J.M. Dent \& Sons Ltd., London.

Kärkkäinen, V-M., 2009, 'The trajectories of the contemporary "Trinitarian Renaissance" in different contexts', Journal of Reformed Theology, 3, 7-21. http:// dx.doi.org/10.1163/156973109X403697

Kessler, D. \& Kinnamon, M., 2000, Councils of Churches and the ecumenical vision, World Council of Churches Publications, Geneva. (Risk Book Series).

Klein, W.W., Blomberg, C.L. \& Hubbard, R.L. (Jr.), (eds.), 1993, Introduction to Biblical interpretation, Word Publishing, Dallas, TX.

Kuypers, K., 1966, Over Kant en zijn betekenis voor onze tijd, Het Wereldvenster, Baarn.

Labuschagne, J.P. (Kobus), 2001, 'Geloofsekerheid in die kerk se geskiedenis van Bybelinterpretasie', HTS Teologiese Studies/Theological Studies 57(3/4), 959-988. http://dx.doi.org/10.4102/hts.v57i3/4.1859

Labuschagne, J.P. (Kobus), 2009, 'Calvin and mission', HTS Teologiese Studies/ Theological Studies 65(1), Art. \#310, 8 pages. http://dx.doi.org/10.4102/hts. v65i1.310

Labuschagne, J.P. (Kobus), 2013, 'The search for oneself: Introductory notes on ethics and anthropology', HTS Teologiese Studies/Theological Studies 69(1), Art. \#1986, 14 pages. http://dx.doi.org/10.4102/hts.v69i1.1986
Labuschagne, J.P. (Kobus), 2014, TEO 124 AIM The method and disciplinary ambit of theology: Study Guide, Pretoria University, Pretoria, p. 25

Labuschagne, J.P., 2015, 'Die Apostoliese tradisie in die Vroeë Kerk se verstaan van Skrif en geloof-'n Kort hermeneutiese oorsig', HTS Teologiese Studies/Theological Studies.http://dx.doi.org/10.4102/hts.v71i3.3017

Letham, R., 2009, 'The Trinity between east and west', Journal of Reformed Theology 3 , 42-56. http://dx.doi.org/10.1163/156973109X403714

Link, H-G. (ed.), 1985, Apostolic faith today - A handbook for study, World Council of Churches, Geneva. (Faith and Order Paper, 124).

Loader, J.A., 1996, "n Hervormde tradisie as heelmiddel', HTS Teologiese Studies/ Theological Studies 52(4), 566-589. http://dx.doi.org/10.4102/hts.v52i4.1543

Lohse, B., 1985, A short history of Christian doctrine, transl. F.E. Stoeffler, Fortress Press, Philadelphia, PA.

Macquarrie, J., 1972, Paths in spirituality, SCM Press, London.

Macquarrie, J., 2003, Jesus Christ in modern thought, SCM Press, London.

McGrath, A.E., 1997, 'I believe' - Exploring the Apostles' Creed, InterVarsity Press, Downers Grove, IL.

McGrath, A.E., 2005, Christian theology: An introduction, Blackwell Publishing, Oxford.

Moltmann, J., 1998, The Trinity and the Kingdom of God - The doctrine of God, transl. M. Kohl, SCM Press, London.

Moltmann, J., 2000, Experiences in theology: Ways and forms of Christian theology, transl. M. Kohl, Fortress Press, Minneapolis, MN.

Pannenberg, W., 1976, The Apostles' Creed - in the light of today's questions, transl. M. Kohl, SCM Press, London.

Rasker, A.J., 1986, De Nederlandse Hervormde Kerk vanaf 1795 - Geschiedenis, theologische ontwikkelingen en de verhouding tot haar zusterkerken in de negentiende en twintigste eeuw, Uitgeversmaatschappij J.H. Kok, Kampen.

Schwöbel, C., 2009, 'The trinity between Athens and Jerusalem', Journal of Reformed Theology 3(1), 22-41. http://dx.doi.org/10.1163/156973109X403705

Smit, D.J., 1998, 'Biblical hermeneutics: The first 19 centuries', in S. Maimela \& A. König (eds.), Initiation into theology: The rich variety of theology and hermeneutics, pp. 275-296, J.L. van Schaik, Pretoria.

Tillich, P., 1974, The courage to be, Collins, London. (The Fontana Library).

Ursinus, Z., 2012, The commentary of Zacharias Ursinus on the Heidelberg Catechism, transl. G.W. Williard, Hardpress, Miami, FL.

Van de Beek, A., 2012, Lichaam en Geest van Christus - De theologie van de kerk en de Heilige Geest, Uitgeverij Meinema, Zoetermeer.

Van den Brink, G., 2009, 'Introduction: The doctrine of the Trinity in Christian faith and global theology', Journal of Reformed Theology 3, 1-6. http://dx.doi. org $/ 10.1163 / 156973109 \times 403688$

Van Selms, A., 1952, Lig uit lig-Die Christelike Geloof volgens die Belydenis van Nicea, HAUM, J.H. De Bussy, Kaapstad,Pretoria.

Walker, W., 1968, A history of the Christian Church, rev. edn., T\&T Clark, Edinburgh.

Young, F.M., 2002, Biblical exegesis and the formation of Christian culture, Hendrickson Publishers, Peabody, MA.

Young, F.M., 2007, The making of the creeds, SCM Press, London.

Young, F.M., 2010, 'Retrospect: Interpretation and appropriation', in F. Young, L. Ayres \& A. Louth (eds.), Early Christian literature, pp. 485-494, Cambridge University Press, Cambridge. 